\title{
Reconstructing a Community, Reclaiming a Playground: A Participatory Action Research Study
}

\author{
Karen Hutzel \\ The Ohio State University
}

\begin{abstract}
This article describes a participatory action research study that examined participants' perceptions of community and of the West End neighborhood in Cincinnati, Ohio, where the study took place. It is argued that oppressive situations have developed strong collective identities and social capital among residents, which can lead to the development of community art as a catalyst for social change and inform community-based art education. An asset-based community art curriculum was implemented and two murals were developed. Results from the study indicate that participants conceive of community, in general, as a safe, happy place that is clean and green, and the West End as a place with strong social bonds despite suffering from trash, violence, and drugs. Results also indicate that participants increasingly realized their own ability to affect change in their community to improve the landscape and promote a cleaner, greener place through art. Data reveal that the community art curriculum contributed to social change in the neighborhood by highlighting the role of neighborhood children and reclaiming a playground that had been associated with drugs and violence.
\end{abstract}

At a community council meeting I attended in the West End neighborhood of Cincinnati, Ohio, in January of 2005, the topic turned again to the community's problems and methods for change. The residents and members of the community council sat on metal folding chairs facing four of the community council's leaders in an arts center located in a small strip mall in the neighborhood. Story upon story was shared of violent acts witnessed throughout the community, as residents often turned to the police captain who was present for legal advice on their situations. The first homicide of 2005 had recently occurred in an apartment complex on Linn Street. A woman had been badly assaulted at a convenience store. The stories continued. An elderly woman who owned a small candy and soda store shared a story about her van being "shot up." The windows were broken out with bullet holes. The librarian said she heard four gunshots one afternoon as she walked a group of preschoolers from the library back to the Head Start building. The stories continued.

As a resident in this neighborhood, I considered my own potential role as an art educator in contributing to and becoming a part of this community through art. However, despite living in this community, I was perceived as an outsider. As an educated white female, I fell into the minority numbers from this primarily low-income African-American neighborhood. At the same time, I represented those who were causing the neighborhood to change to a more mixed-income, racially and
Correspondence regarding this article may be sent to the author at The Ohio State University, 258B Hopkins Hall, 128 North Oval Mall, Columbus, $\mathrm{OH} 43210$. E-mail: hutzel.4@osu. edu 
economically diverse community, a change the current community did not necessarily endorse. I had moved into the West End in August of 2003, with my partner, an African-American man who had lived in this neighborhood at several points in his life. His brother's family lived in a public housing complex in the neighborhood for the past 10 years and were just down the street from our new townhome. Despite these connections, I still carried an outsider status to those who did not know me, and I had to realize the perceptions and the realities of oppression and racism among the residents over the years (Apple, 1995; Sleeter \& Grant, 1999). I had to learn to listen and continue to build relationships in the community prior to becoming a contributing member of the community and to being able to conduct a research study with them (Hutzel, 2006). My skin color and demeanor contributed to my outsider status, which was reinforced to me at several community council meetings and often when I walked my dog in the neighborhood. I did not necessarily or initially fit into this community and spent the next 10 months building relationships prior to conducting the study (Hutzel, 2006).

In this article, I present a participatory action research (PAR) study examining the participants' perceptions of community in general and specifically of their West End neighborhood through a pragmatic approach connecting theory to reality, what West (1989, p. 151) has called "a theology of the streets." The action research method supported a pragmatic approach toward making this connection, while the narrative results of this study provide a critical connection to the theories presented here. As a participant in this study, my own perceptions and learning were central to the study's goals, as I implemented the study to create social change and inform theories of community art education (McNiff, Lomax \& Whitehead, 2003).

I implemented an asset-based community art curriculum to examine participants' sense of community and as an attempt to encourage social reconstruction through action. The curriculum incorporates social action methods of art education (Anderson \& Milbrandt, 2005; Bastos, 1998), service-learning (Taylor, 2002, 2004), community art (Adejumo, 2000; Emme, 1998), and community development (Green \& Haines, 2002; Kretzmann \& McKnight, 1993) in recognizing the important role of local residents in the sustainable regeneration of their community. In this article, I theoretically and pragmatically examine the collective identities and perceptions of this urban, African-American community, actively considering my methods as a researcher and art educator in this community. Ultimately, I propose a curriculum that responds to the assets exposed by the community. These goals respond to the foundation of action research, as McNiff, Lomax and Whitehead (2003) outline to include that which is practitioner based, focuses on learning, can lead to 
personal and social improvement, responds to social situations, is intentionally political, and focuses on change, with the self as the locus of change. This study attends to these theories through the action research agenda, beginning with my experience learning and teaching in the West End neighborhood.

\section{The West End Neighborhood}

The West End neighborhood is an inner-city, primarily AfricanAmerican community located a few blocks from the downtown Cincinnati business district. In the year 2000, 8,115 people resided in the West End (United States Census Bureau, 2000). From 1990 to 2000, the West End experienced a 29\% decrease in overall population and a $25 \%$ increase in white population as the black population dropped from $94 \%$ in 1990 to $87 \%$ in 2000 . The increase in white population, from 681 people in 1990 , to 850 in 2000 , despite overall population decline, may be attributed to recent community development initiatives, as several housing projects had been torn down to make room for a new mixed-income housing development spanning several blocks of land. I lived in a rental unit in this new housing development, and thus represented to many residents an outsider in the neighborhood. For instance, the first several times I presented this research project at community council meetings in the West End, perhaps because of my perceived role as an outsider, I was met with some hostility and a lot of questions. Some questioned my intentions and some questioned my ability to teach urban black children (Hutzel, 2006).

Children dominate the streets and sidewalks of the West End neighborhood. Census data of 2000 indicated that children made up 30\% of the West End population. Of the 2,511 children the 2000 census reported living in the West End, 95\% were African American. Relevantly, there had been many recent educational development projects in the West End, which attended to creating places for children's activities. For instance, the Lincoln Community Center recently reopened after major renovations, and a new Head Start building was built in the neighborhood in 2003. The neighborhood YMCA had been undergoing a building redevelopment project on the same street, which I became involved with during this study when I was asked to serve on and "diversify" the board. Each of these services, in addition to the Arts Consortium, was located within a block of each other on a busy street in the West End: Linn Street. From the family room window of my rented townhome, I could see most of these buildings on Linn Street and could hear the sound of kids' voices and music playing. One of my favorite sounds was of a particular boy who skillfully played his drumsticks on any available surface or wall. 
Despite the many assets of the West End, the neighborhood also faced the highest murder rate in Cincinnati in 2003, comprising 13\% of the total murders in the city. Poverty, drugs, and prostitution were commonplace in the neighborhood. Trash was commonly found on the streets and sidewalks. Drug dealing was rampant. While there were many children in the area, there were few outdoor areas for play and exercise. In my experience living in the neighborhood, I found basic city services such as snow clearance and trash pick-up inconsistent. I was discovering a shocking difference between my experience living in working- and middle-class neighborhoods and my experience living in this neighborhood. The notion of being marginalized and oppressed that had been presented to me by residents at the community council meetings was becoming very real to me through hearing about their experiences. But at the same time, I found a strong sense of commitment, community, and family in the West End that inspired me to want to learn more.

\section{Community, Collective Identity, and Art}

Even while those within marginalized, minority, or low-income populations tend to experience a much stronger social identity and sense of community than more middle and upper-class communities (Apple, 1995; Green \& Haines, 2002), overall the spirit of community has been suffering for many years (Keyes, 1973). In lower-income neighborhoods, such as the West End, residents are often forced to move out of their neighborhoods in the name of development. Social relationships, whether within families, schools, or communities, have changed: children often travel to schools far from their neighborhoods, return to empty houses, and move so often they have little chance of getting to know their neighbors (Putnam, 2000). In the same dilapidating way, schools, which often teach competitive and bureaucratic individualism, often fail to meet the needs of marginalized youth who have learned to survive through collective identities (Sleeter \& Grant, 1999). Failing educational systems and weakened social structures then perpetuate systems of oppression (Sleeter \& Grant, 1999).

Given that the arts speak culturally, ritually, and socially (Dissanayake, 1988), the use of community art to expose and nurture inherent collective identities of minorities (Lowe, 2000) can provide a catalyst for change through local community development (Jones, 1988) and regeneration (Kay, 2000). Bastos (1998) presented art education in light of social responsibility and action through community-based art education as a social activist approach, which can address a community's needs through recognizing the social capital in the community. Gude (2000) engaged others in artmaking through social action approaches and has translated her collaborative artmaking strategy into her university teaching. Meanwhile, Anderson (2003) summarized the significance of the under- 
lying connection between art and sustainable community regeneration, stating, "the survival value of art lies in its community-making function" (p. 63). Congdon (2005) described what she has learned from "other" art educators, claiming certified art educators often "tend to ignore folk artists' ways of understanding the world" (p. 138). These "other" art educators are often more deeply involved with the communities where they teach and can provide approaches to teaching that attend to the needs of the community. Congdon's message suggests a possibility for art education to promote more pragmatic approaches to research and teaching by recognizing the lessons offered by "other" communities.

Research in service-learning (Taylor, 2002, 2004), community-based art education (Ulbricht, 2005), and various socially reconstructive art education practices (Blandy, Branen, Congdon \& Hicks, 1991; Emme, 1998; Lai \& Ball, 2002; Wexler, 2002) are based on a common socially conscious philosophical foundation. Service-learning has been described as a postmodern approach to art and teaching (Taylor, 2002) and a method for teacher training and developing a sense of place in college students (Taylor, 2004). Additional socially responsive approaches to art and art education attend to people with disabilities (Wexler, 2002) and various cross-cultural considerations and collaborations (Ross, 2004; Staikidis, 2006). Ulbricht (2005) offered community-based art education as an umbrella for such a variety of art education practices. $\mathrm{He}$ encouraged us to broaden our concept of community-based art education as one that will "promote contextual learning about local art and culture" (p. 6), which includes informal teaching, outreach, ethnography, and public art.

The community art curriculum I present in this action research study intends to create change, empower participants, and deconstruct single voices of authority through critical practice (Freire, 1993; hooks, 1994). As a social activist and educator, Freire (1970/1994) advocated a "committed involvement" in working for change in a community that has experienced oppression. He suggested "the solution is not to 'integrate' those communities into the structure of oppression, but to transform that structure so that the community members can become "beings for themselves"' (Freire, 1970/1994, p. 48). Influenced by Freire's work, hooks (1994) argued for a collective critical practice, in which there is more than one single voice of authority. She promotes the deconstruction of a privileged voice through collective critical practice, which re-emphasizes the role of social networks and group learning in a community context. Freire and hooks both describe education for liberation with oppressed communities through a group process of understanding the perceptions and goals of the participants, which forms the philosophical and theoretical foundation of this action research study and the community art curriculum. 
${ }^{1}$ The Institutional Review Board of the Florida State University approved of the research methodology.

\section{Methodology}

Based on multiple methodologies, I implemented this qualitative study in the spring and summer of 2004 to examine participants' perceptions of community through active engagement in creating assetbased public community art in the form of two murals. ${ }^{1}$ The qualitative approach seeks to ground theory in contributing to social justice (Charmaz, 2005) and is informed by ethnography, phenomenology, case study design, and, particularly, participatory action research. Ethnography (Douglas \& Valenzuela, 2005; Tedlock, 2005) provided a methodological framework for using the techniques of observation, interviews, and documentation collection in a cross-cultural study. Phenomenology (Neville, 2002) informed my ongoing analysis of the data as a personal and perceptual process of reflection and critical interpretation. Finally, constructing the methodology as a case study (Stake, 2005) provided the structure for considering a particular place and participants. The data collected allowed me to consider various participants' perceptions of the community and the community art process. Accordingly, my own perceptions and understandings of the participants and the West End community were examined through the process.

The action research methodology was structured to actively engage participants, including myself, in the community of the West End in and through art and brought attention to ethical issues of researcher trust and responsibility by considering the participants as equal contributors to the work (Brydon-Miller, Greenwood \& Eikeland, 2006). Accordingly, "Action research offers its practitioners the opportunity to engage communities as equal partners in addressing important concerns while improving practice and deepening our shared understanding of crucial issues" (Brydon-Miller et al., 2006, p. 129). To reach this research goal, participants engaged in several curricular activities that additionally generated important data in the research. First, youth participants examined their personal sense of community through a drawing activity in which I asked them to draw their "idea of community." The drawings were utilized in an interview with each youth about their perceptions of community. Participants then more fully examined this specific community through an asset-based mapping exercise to locate good things already existing in the neighborhood. Through these methods, we identified a location and concept for creating two murals to highlight our learning and respond to our findings.

In conducting this study, I addressed the primary research question: What does the implementation of an asset-based community art curriculum in the West End neighborhood of Cincinnati, Ohio, reveal about participants' perceptions of community, and how does it contribute to social change? 
Participatory action research. Participatory action research, as the guiding framework for planning and conducting this study, is founded on a social reconstructionist agenda which seeks change through action and education with oppressed classes of people (Foucault, 1980). With transformation as a goal of participatory action research (Brydon-Miller, 2001; Kemmis \& McTaggart, 2000), the placement of this study in an oppressed community served to approach research from a changeoriented perspective, rather than passive observation of existing events (McNiff, et al., 2003).

As a strength of PAR studies, the researcher and the participants are deeply involved in the activities being studied. In this regard, BrydonMiller (2001) suggested, "The success of any PAR project depends on the depth of mutual trust and commitment held by all participants" ( $p$. 81). As I indicated earlier, as an outsider, I was not initially trusted in this community and discovered I had to demonstrate my commitment in order to gain participants' trust.

Location and participants. I initiated this study with the Arts Consortium, an African-American community arts center located in the West End neighborhood. The Arts Consortium has had a long history of community arts education in the African-American community in Cincinnati. The Arts Consortium has offered arts education courses and provided a gallery space for local artists. In the 2004 summer program, youths took arts classes ranging from painting and quilting to dance and drama, but had not actively participated in communitybased efforts focused on the West End prior to this study, according to the education director. In addition, the program operates an AfricanAmerican museum located in the museum center at Union Terminal. Based on my past work with Jolynn, ${ }^{2}$ the curator of the museum, I was able to build on the relationship I had previously established with her in another neighborhood to implement this study with the center's participants (Hutzel, 2006).

In an effort to further engage the community in the study, I also presented the project to the West End Community Council and asked for their feedback and participation. Upon the invitation, the executive director of the Lincoln Community Center asked to have the youths in her summer program participate. The Lincoln Community Center, located two blocks from the Arts Consortium, had recently been redeveloped and offered a weight room, a gymnasium, outdoor swimming pools, classrooms, and meeting spaces.

Approximately 8 to 10 youths ranging in age from 10 to 16 from the Arts Consortium, and a fluctuating 8 to 15 youths ranging in age from 10 to 14 from the Lincoln Community Center participated in the study throughout the summer. While the children from the Arts Consortium had participated in arts educational activities in their summer program,

${ }^{2}$ Names of participants have been changed. 
most of the children from the Lincoln Center had experienced fewer opportunities for learning in the arts. Several decisions with regard to participation in the creation of the murals were impacted by this dichotomy, as we wished for the youths with less arts experience to feel as much a part of the mural development as the others.

In addition to the youths, several adults were involved in the study. Alex, a young white woman and new art teacher in the Cincinnati Public School district, acted as the lead artist and supervisor of the youths from the Arts Consortium. Her role was important in implementing the curriculum and developing the artwork with the youths. Additionally, Richard was the supervisor of the youths from the Lincoln Community Center and took on a prominent role in examining this community by sharing his experiences as a child growing up in the neighborhood in the 1960s. Jolynn and Donna, both from the Arts Consortium, were important to the functioning of the program and in offering suggestions for working with the children. Frank, the president of the West End Community Council, participated in the study by making important community connections, assisting with gaining permission to paint on a city wall, and encouraging the media to report on the story. Two other West End residents, Kevin and Wayne, also assisted with the implementation of the project: Kevin helped paint and offered encouragement to the youths and Wayne helped gain permission to paint a second mural. In addition, several other adults came into and out of the study in various capacities throughout the summer.

\section{Asset-Based Community Art Curriculum}

Asset-based community development is intended to "increase the capacity of the residents to improve the quality of life" (Green \& Haines, 2002 , p. vii). By focusing on the assets in the community, including social, physical, environmental and human, the philosophical goals of the study are reinforced to create reciprocity and respond to the resources already existent in the neighborhood. Need-based approaches, on the other hand, can contribute to the promotion of the powerless, by creating an atmosphere in which "lower income urban neighborhoods are now environments of service where behaviors are affected because residents come to believe that their well-being depends upon being a client" (Kretzmann \& McKnight, 1993, p. 2). The asset-based component of this community art curriculum as action research serves to recognize the participants and the community as being resources and not merely problems to be solved (McNiff et al., 2003).

The community art curriculum served to examine participants' perceptions of the community through their participation in the community art project, their drawings and asset-based maps of the community, and interviews. Additionally, the youths participated in determining the 
logistics of creating the two murals, including choosing the location and conceptual framework. Their opinions, ideas, and perceptions were central to the development of the art pieces. The asset-based process involved the participants in mapping a part of the neighborhood in small groups, using maps and disposable cameras, with the goal of attending to the assets in the neighborhood. The photographs were then used in drawings of larger maps of the areas each group explored, with the resulting drawings shared with the class. This process was repeated a second time once the decision was made by the group to develop a mural in the neighborhood. The second time, the small groups photographed walls as potential mural sites and presented their top choices to the group.

Utilizing service-learning as the pedagogy provided a foundation for implementation of the curriculum. Four components of servicelearning-preparation, action, reflection and recognition-framed the process of engaging the participants in the community art project in conjunction with the goals and strategies of the study as participatory action research (Duckenfield \& Wright, 2001). The preparation component involved the asset-based mapping exercise and process of conceptual development for the murals. The action component involved the creation of the public community art: in this case, two murals. The reflection took place in writing and drawing exercises, group discussion, and personal interviews. Finally, the recognition component involved a recognition event to present the murals to the community. The story of our work in the West End will highlight these four components while revealing the participants' sense of community and our perceptions of the social change we created.

\section{Participants' Perceptions of Community}

The Arts Consortium youths were asked to draw "their idea of community" at the beginning of June and were interviewed about their drawings and perceptions of community. Not all of the youths lived in the West End, so their drawings, interviews, and answers in response to questions specifically about the West End were informed by their own living situations. However, most of their drawings and comments represented ideal or fantasy visions of community, while exposing their personal fears and problems with some of their urban neighborhoods.

Shanda, a 16-year-old West End resident, for instance, described her community drawing as an ideal place: " "I just want it to be like this... We a long way off. People need to care more about where they live and what they do." Shanda's sister had been hit by a car and died about 10

${ }^{3}$ Youths provided descriptions of their drawings in interviews. years ago, when Shanda was only 6 and her sister only 10. Shanda, a quick and smart girl who attended a construction charter school in the neighborhood, softened when describing her loss. 
Lyzbeth, a 15-year-old from another urban neighborhood in Cincinnati, described her community drawing as a fantasy world. "Basically you leave your doors unlocked when you walk out. You ain't got to worry about nobody breakin' in your house and takin' your stuff." Lyzbeth dressed stylishly and was athletic and smart, but was living in several different places and suffering from stress causing stomach pains that landed her in the emergency room during our study.

Shai, a 10-year-old West End resident, described community as "a place where people should be happy, but they are not happy because it's too much violence.... It is not that great where I live because everybody is being all loud at night and stuff." Shai was quiet and attentive and attended a local public arts school.

The youths' drawings and interviews represented community as a happy, safe, sunny place with buildings, trees, birds, and kids playing without worry. Three basic components of community they identified included safety, greenery and cleanliness. And, although many of the youths denied that these factors were present in their own communities, they seemed to share a wishful optimism about the possibility for change.

The participants were also asked in interviews about their perceptions of the West End community. They said social networks and activities in the neighborhood were their favorite things about the West End. Also present was their sense of hopelessness resulting from their perceptions of trash, violence, and drugs. When asked about their favorite things about the West End, participants mentioned most often social activities, parks, and meeting centers (specifically the Arts Consortium and the Boys and Girls club). Richard, the supervisor from the Lincoln Community Center, said, "Well, everybody knows each other." When asked what they did not like about the West End, the youths mentioned crime, fights, and trash. Richard described the crime and violence as a product of people's unwillingness to turn each other in for fear of repercussions. The youths described ways to make the West End better, including people working together and helping out, picking up trash, and more parks and places for kids to play. The participants also identified many assets in the neighborhood through the asset-based mapping process, including churches, parks, playgrounds, stores, schools, barbershops, the library, the Arts Consortium, and the Lincoln Community Center. These locations seemed to be very important social places for the youths.

Shanda, who had lived in the West End all 16 years of her life, reflected on the asset-based mapping process in which she identified several buildings she felt contributed to the community:

I have lived in the West End my whole life. I never knew that we had all of those assets in our community. I never really paid 
any attention to those buildings.... It is really good to know that a community like the West End has so many historic buildings around. I like the experience of walking around my town. At first when we began to walk I was like 'Why we walking around Downtown? There is nothing here to see.' Then when we started to see all the historic buildings I began to think to myself, 'Is all these buildings down the way?' I really never hardly looked at these buildings (assets). I realized that the West End is really a nice place to be.

Her reflection highlighted the absence of an asset-based mindset, where urban communities are often more accustomed to considering their neighborhoods from a need-based framework.

\section{Creating Change Through Art}

As we considered our findings about the West End, we discussed how we could respond through art. When I suggested we consider creating a public, community art piece to highlight the assets of the community, the youths expressed interest in creating a mural. After some discussion, we scanned the neighborhood in small groups again in order to identify possible walls on which to create our mural. Through this process, I learned the youths wanted to create a permanent mural, as opposed to one done on plywood coverings. Lyzbeth told me she wanted to be able to show her kids her mural someday, so she wanted to create one on a permanent surface. We narrowed down our choices to three and attempted to gain permission from the owners of the walls, with the help of Frank and Wayne, both from the community council. We identified two walls, both on either side of a small grassy area in the West End that had received much attention from the community to reclaim it from a gang known as the Tot Lot Posse. This playground had received a lot of attention on the local news as well as at the community council meetings, as the residents had been struggling with ways to reclaim the area from these drug dealers and gang members. The main wall of our focus was a 3-foot tall retaining wall surrounding the playground. The second wall was on a house on the other side of the Tot Lot area, and was much more visible to the street traffic. We chose to do this second mural because the youths expressed interest in showing those who drove through the neighborhood that the kids in the West End were good. Both walls were on Linn Street and traffic was heavy.

Building on the youths' desires for a cleaner community and their focus on kids and social activities, we developed a theme for the murals reflecting the developmental importance of kids playing and imagining. We asked the youths to draw or write about things they used to imagine when they played on a playground. Although some showed hesitation, they soon opened to this activity. One boy, for instance, 
drew himself on a swing, flying off as Superman and into a burning building to save people from a fire. Lyzbeth and Shanda, the older of the youths, worked together on an image of a boy kicking a football that turned into a spaceship. We recognized their dreams of contributing to their community and becoming successful. This theme and the final design incorporated this as well as the youths' interests in kids, safety and greenery.

Because many of the youths from the Lincoln Center were not comfortable with their drawing skills, Alex, our lead artist, developed the design based on all of the youths' drawings. The youths also practiced painting the mural on butcher paper before doing so on the wall. When we started to paint the mural on the wall, several youths seemed afraid to "mess it up." Once they felt more comfortable, they migrated to painting the areas of the mural that were their own original ideas (see Figures 1 and 2). We spent 2 weeks painting the murals, after 7 weeks of planning, and culminated our experience with a recognition event that

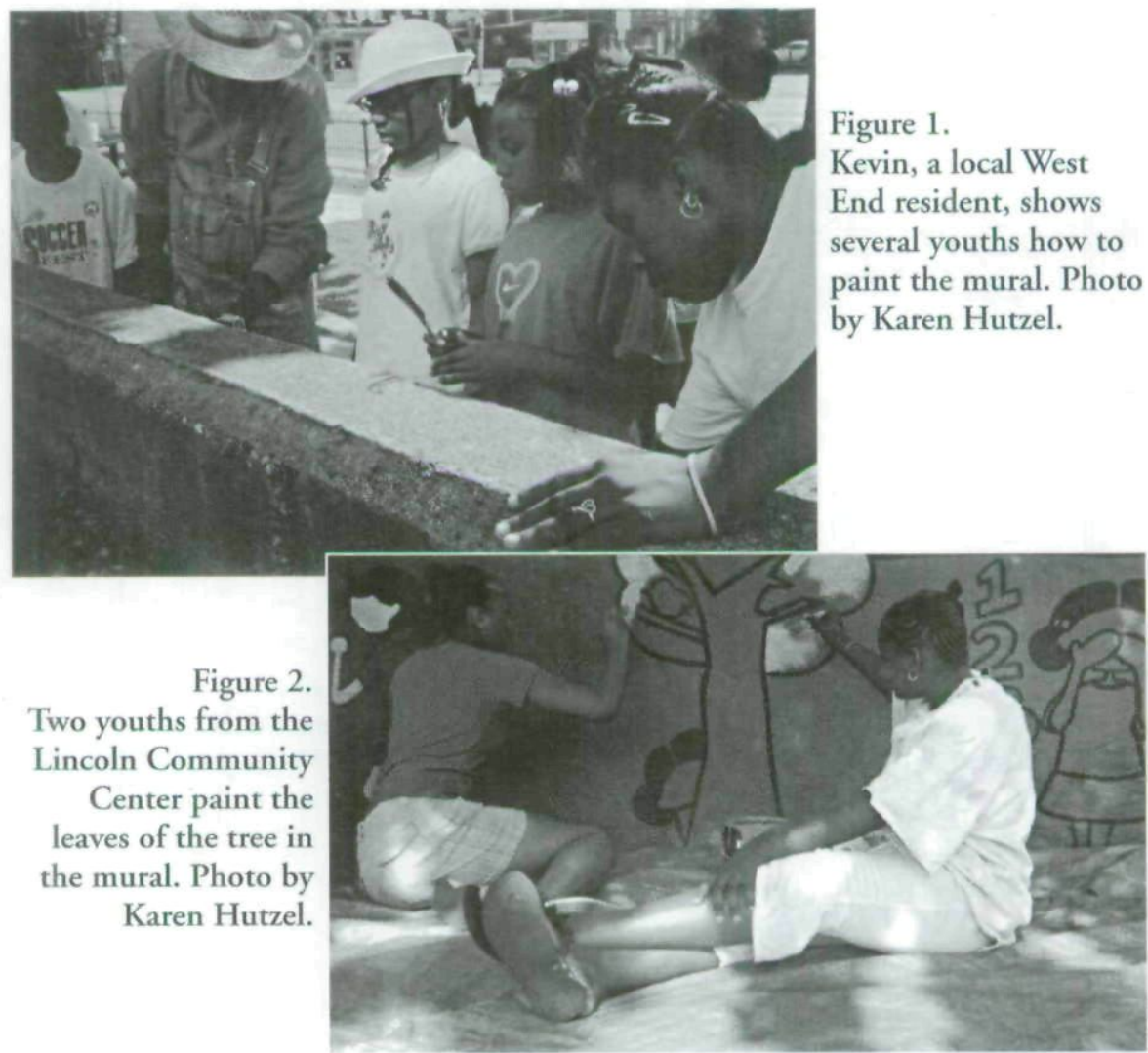




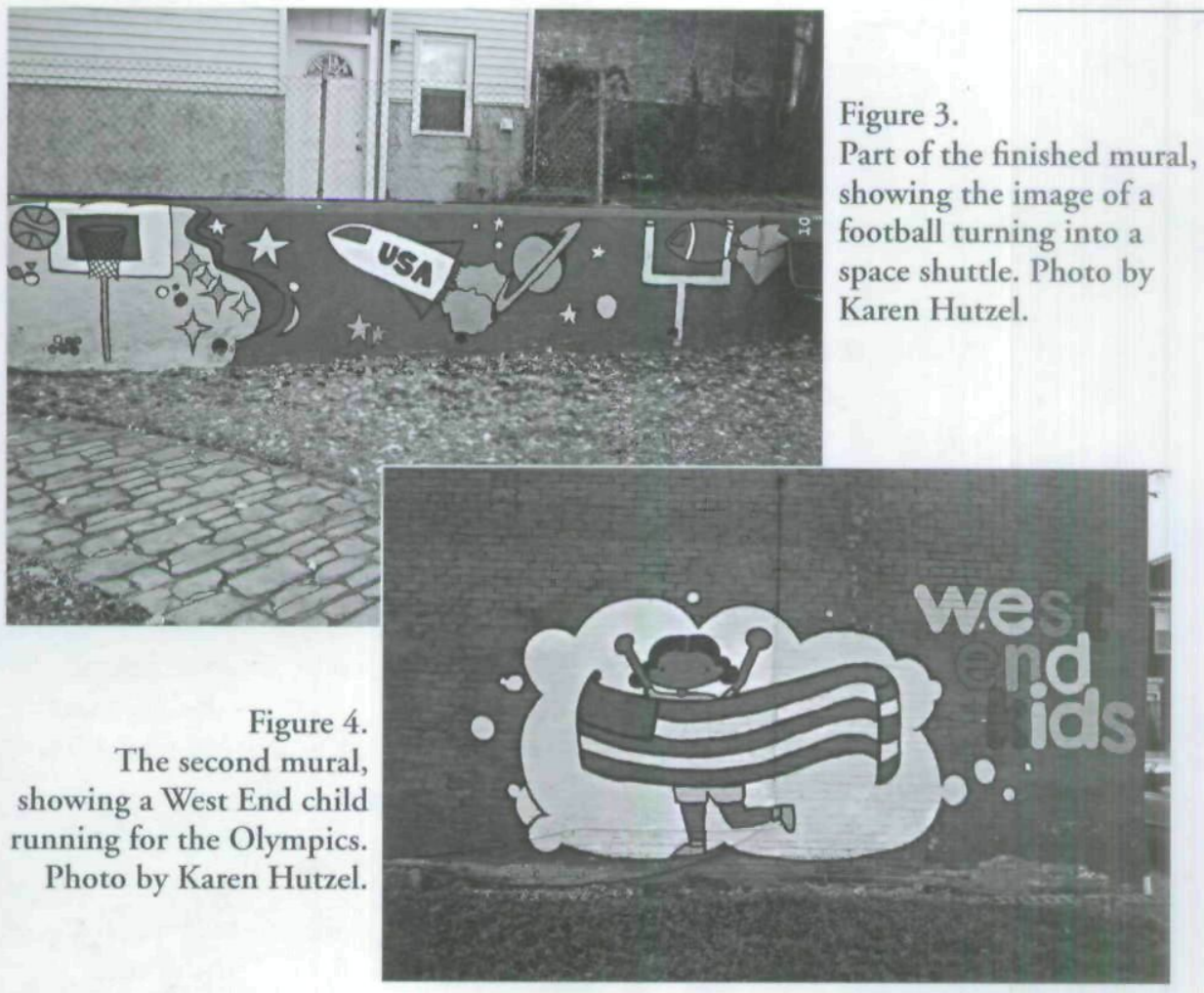

appeared on several of our local news stations. The youths expressed great pride in their work when they were at the event and the news cameras were present. The youths were happy to see their ideas in the murals and expressed pride for their accomplishment (see Figures 3 and 4).

Richard, the supervisor from the Lincoln Community Center, expressed the impact he felt our work had on the community. In describing the murals and the community art curriculum, he quietly stated:

So the seed has been planted. That mural is a seed. When kids walked by there, their parents would probably say, 'We are not going to that park.' That is before that mural. Now they see that mural as a token for kids to now enter... So that mural has taken back the idea they were kids. It has probably done scared away some of the dope dealers, too. So it is a double-edged thing here. It is a sense of taking back without even saying a word.

Frank, the president of the West End Community Council, claimed the playground was being used more by kids, instead of grown men, and soon after the recognition event housed a birthday party with balloons hanging all around. 
The project reminded us of our potential to create and affect change at a local level. While the participants recognized their own abilities to affect change, the finished murals left behind a lasting memory of our effort. The possibilities for art to create change in the West End are continuing to be explored, as Cincinnati arts organizations have developed a collaborative with the West End community to continue to develop projects to benefit the neighborhood and empower the residents. And as of this writing, I am still involved in this community through this effort and my continued work with the neighborhood YMCA. When I asked Donna, from the Arts Consortium, why I had received so much apprehension from the community when I first started the relationship, she commented, "This community has been, for lack of better words, 'pimped' so much." I felt assured by Donna and several community members that our work with the neighborhood had not contributed to "pimping" it. She indicated others had made promises that were not fulfilled, leaving the community to assume the effort had been an attempt to acquire funding at the community's expense. By finishing this project and working with children in the community through the entirety of the summer, and continuing my involvement since then, I showed a commitment to the community.

\section{Conclusion}

The collective identities (Apple, 1995), strong social identity (Green \& Haines, 2002) and strong sense of community (Hillier, 2002) found within the African-American community in past studies were revealed again in this study, emphasizing the need for more research about collective learning styles with regard to art education. While education generally continues to stress competitive and individualistic notions (Sleeter \& Grant, 1999), the tendency I encountered in the West End when youths are encouraged and facilitated toward it was the value of community engagement. My interviews with the youths and the adults revealed a deep-rooted commitment to improving the lives in their community, whether that meant their neighborhood community, their African-American community, or more generally, the community of those suffering from oppression. Many of the people I encountered in this neighborhood, while fearful of outsiders entering their community, were still selflessly hopeful and perhaps convinced that change would take place for their community. As I experienced several initial negative comments toward my own presence, I witnessed the fear and distrust many felt toward those they considered outsiders. At first I was insulted by some residents' reactions toward me, but I quickly came to realize that there had been many people before me who perhaps looked like me but who had made false promises to this community. It was apparent to me that the combination of a participatory action research methodology 
and community-based art education for social change developed a level of trust from the community. As they were treated as equal participants in the study, they came to understand and value the work that addressed the long-neglected community needs.

This study exemplifies the needs of an urban, lower-income neighborhood and its youths through a community art curriculum intended to engage the community in an asset-based approach to art creation and social change. As the results of the study suggest, it is necessary for the field of art education to examine the collective identities of lowerincome, minority, and African-American communities in order to develop pedagogy to meet the needs of youths living in such oppressed communities. The implications also reveal the need for more theoretical and pragmatic research in the areas of community-based art education, collective learning styles, and methods for activist art education.

The realities of many communities-shootings, drug dealing, assaults - can make an art class seem frivolous to a person living with a daily fear of violence. This study suggests that an art curriculum that incorporates these realities by acting toward change can incite active engagement in art and community development. Thus, art educators can benefit by attempting to understand and learn from the communities in which they teach through the eyes and experiences of the students and community residents and strive to meet the real needs that are presented.

\section{References}

Adejumo, C. O. (2000). Community-based art. School Arts, 99(6), 12-13.

Anderson, T. (2003). Art education for life. The International Journal of Art and Design Education, 22(1), 58-66.

Anderson, T., \& Milbrandt, M. (2005). Art for life: Authentic instruction in art. New York: McGraw-Hill.

Apple, M. W. (1995). Is social transformation always progressive? Rightist reconstructions of schooling today. In M. James (Ed.) Social reconstruction through education: The philosophy, bistory, and curricula of a radical ideal. (pp. 1-26). Norwood, NJ: Ablex Publishing Corp.

Bastos, F. M. C. (1998). Making the familiar strange: Teachers' interpretations of community art. Dissertation Abstracts International, 60 (05), 1425. (UMI No. 9932612)

Blandy, D., Branen, K., Congdon, K. G., \& Hicks, L. E. (1991). The NAMES quilt and the art educator's role. The Journal of Social Theory in Art Education, 11(1), 102-117.

Brydon-Miller, M. (2001). Research and action: Theory and methods of participatory action research. In D. L. Tolman \& M. Brydon-Miller (Eds.), From subjects to subjectivities: A handbook of interpretive and participatory methods. (pp. 76-89). New York: New York University Press.

Brydon-Miller, M., Greenwood, D., \& Eikeland, O. (2006). Conclusion: Strategies for addressing ethical concerns in action research. Action Research, 4(1), 129-131. 
Charmaz, K. (2005). Grounded theory in the 21st century: A qualitative method for advancing social justice research. In Norman K. Denzin \& Yvonna S. Lincoln (Eds) The Sage handbook of qualitative research. (pp. 507-536). Thousand Oaks, CA: Sage Publications, Inc.

Congdon, K. G. (2005). What I have learned from "other" art educators. Studies in Art Education, 46(2), 138-149.

Dissanayake, E. (1988). What is art for? Seattle, WA: University of Washington Press.

Douglas, F., \& Valenzuela, A. (2005). Critical ethnography: The politics of collaboration. In N. K. Denzin \& Y. S. Lincoln (Eds.), The Sage handbook of qualitative research (pp. 217-234). Thousand Oaks, CA: Sage Publications, Inc.

Duckenfield, M., \& Wright, J. (2001). Pocket guide to service-learning. Clemson, SC: National Dropout Prevention Center.

Emme, M. J. (1998). Teaching to the future: Community activism and art education. School Arts, 975), 6-7.

Foley, D. \& Valenzuela, A. (2005). Critical ethnography: The politics of collaboration.

In N. K. Denzin \& Y. S. Lincoln (Eds.), The Sage handbook of qualitative research (pp. $217-$

234). Thousand Oaks, CA: Sage Publications, Inc.

Foucault, M. (1980). Power-knowledge: Selected interviews and other writings, 1972-1977. New York: Pantheon Books.

Freire, P. (1970/1994). The Paulo Freire reader. New York: Continuum International Publishing Group, Inc.

Freire, P. (1993). Pedagogy of the oppressed. New York: Continuum International Publishing Group, Inc.

Green, G. P., \& Haines, A. (2002). Asset building and community development. Thousand Oaks, CA: Sage Publications.

Gude, O. (2000). Drawing color lines. Art Education, 53(1) 44-50.

Hillier, J. (2002). Presumptive planning: From urban design to community creation in one move? In A. T. Fisher, C. C. Sonn, \& B. J. Bishop (Eds.), Psychological sense of community: Research, applications, and implications (pp. 43-67). New York: Kluwer Academic / Plenum Publishers.

hooks, b. (1994). Teaching to transgress: Education and the practice of freedom. New York: Routledge.

Hutzel, K. (2006) Developing relationships: A reflection on my experience learning with a community. In Roy, R. K. \& Cho, M. (Eds.), My art... my world: A handbook on service learning in the art classroom (pp. 13-16). Tallahassee, FL: Florida Learn and Serve.

Jones, B. (1988). The community artist as community development catalyst: An evaluation of a pilot project. Journal of the Community Development Society. 19(1), 37-50.

Kay, A. (2000). Art and community development: The role the arts have in regenerating communities. Community Development Journal. 35(4), 414-424.

Kemmis, S., \& McTaggart, R. (2000). Participatory action research. In N. K. Denzin \& Y. S. Lincoln (Eds.), Handbook of qualitative research. (pp. 567-605). Thousand Oaks, CA: Sage Publications, Inc.

Keyes, R. (1973). We the lonely people: Search for community. New York: Harper-Row.

Kretzmann, J. P., \& McKnight, J. L. (1993). Building communities from the inside out: A path toward finding and mobilizing a community's assets. Chicago: ACTA Publications.

Lai, A., \& Ball, E. L. (2002). Home is where the art is: Exploring the places people live through art education. Studies in Art Education, 44(1), 47-66. 
Lowe, S. S. (2000). Creating community: Art for community development. Journal of Contemporary Ethnography, 29(3), 357-386.

McNiff, J., Lomax, P., \& Whitehead, J. (2003). You and your action research project (2nd ed.). London: Routledge Falmer.

Neville, R. C. (2002). Phenomenology and pragmatism. In B. E. Babich (Ed.), Hermeneutic philosophy of science, Van Gogh's eyes, and God: Essays in honor of Patrick A. Heela (pp. 323-338). Boston, MA: Kluwer Academic Publishers.

Putnam, R. D. (2000). Bowling alone: The collapse and revival of American community. New York: Simon \& Schuster.

Ross, M. (2004). Art at the crossroads: The contested position of indigenous arts in Ghana's postcolonial education systems. Studies in Art Education, 45(2), 117-134.

Sleeter, C. E., \& Grant, C.A. (1999). Making choices for multicultural education: Five approaches to race, class, and gender. Upper Saddle River, NJ: Prentice-Hall, Inc.

Staikidis, K. (2006). Personal and cultural narrative as inspiration: A painting and pedagogical collaboration with Mayan artists. Studies in Art Education, 47(2), 118-138.

Stake, R. E. (2005). Qualitative case studies. In N. K. Denzin \& Y. S. Lincoln (Eds.), The Sage Handbook of qualitative research (pp. 443-466). Thousand Oaks, CA: Sage Publications, Inc.

Taylor, P.G. (2002). Service-learning as postmodern art and pedagogy. Studies in Art Education, 43(2), 124-140.

Taylor, P.G. (2004). Service-learning and a sense of place. Journal of Cultural Research in Art Education, 22(1), 33-44.

Tedlock, B. (2005). The observation of participation and the emergence of public ethnography. In N. K. Denzin \& Y. S. Lincoln (Eds.), The Sage handbook of qualitative research (pp. 467-482). Thousand Oaks, CA: Sage Publications, Inc.

Ulbricht, J. (2005). What is community-based art education? Art Education, 58(2), 6-12.

United States Census Bureau. (2000). Cincinnati population: Race, age by statistical neighborhoods. Prepared by Cincinnati City Planning. Retrieved December 11, 2005, from http://www. cincinnati-oh.gov/cdap/pages/-3627-1

West, C. (1989). The American evasion of philosophy: A genealogy of pragmatism. Madison, WI: University of Wisconsin Press.

Wexler, A. (2002). Painting their way out: Profiles of adolescent art practice at the Harlem Hospital Art Studio. Studies in Art Education, 43(4), 339-353. 
Copyright of Studies in Art Education is the property of National Art Education Association and its content may not be copied or emailed to multiple sites or posted to a listserv without the copyright holder's express written permission. However, users may print, download, or email articles for individual use. 